Canadian Journal of Higher Education

Revue canadienne d'enseignement supérieur

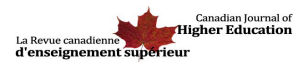

\title{
Sinking or Swimming in an Academic Pool: A Study of Resiliency and Student Success in First-Year Undergraduates
}

\section{Claire A Wilson, Sarah E Babcock and Donald H Saklofske}

Volume 49, Number 1, 2019

URI: https://id.erudit.org/iderudit/1060824ar

DOI: https://doi.org/10.7202/1060824ar

\section{See table of contents}

Publisher(s)

Canadian Society for the Study of Higher Education

ISSN

2293-6602 (digital)

Explore this journal

Cite this article

Wilson, C., Babcock, S. \& Saklofske, D. (2019). Sinking or Swimming in an Academic Pool: A Study of Resiliency and Student Success in First-Year Undergraduates. Canadian Journal of Higher Education / Revue canadienne d'enseignement supérieur, 49(1), 60-84. https://doi.org/10.7202/1060824ar
Article abstract

The transition from high school to post-secondary education presents challenges for students. Many variables have been identified as significant predictors of student achievement. Resiliency, defined as the ability to overcome challenges and adversity, may be particularly relevant during the adjustment to post-secondary education. This study assesses whether resiliency incrementally predicts student success after controlling for additional predictors. Participants were 277 undergraduate students who completed self-reports of academic skills, resiliency, personality variables, emotional intelligence (EI), and perfectionism. Students' year-end GPA was collected from the university registrar. Hierarchical regression analysis revealed that resiliency, measured by sense of mastery, negatively predicted GPA after controlling for other predictors. The sense of mastery facet of self-efficacy positively predicted GPA; however, the adaptability facet was a significant negative predictor of GPA. Findings suggest that self-efficacy is a salient predictor of academic success, and that strong academic skills may serve as a protective factor for poor adaptability.
This document is protected by copyright law. Use of the services of Érudit (including reproduction) is subject to its terms and conditions, which can be viewed online.

https://apropos.erudit.org/en/users/policy-on-use/ 


\title{
Sinking or Swimming in an Academic Pool: A Study of Resiliency and Student Success in First-Year Undergraduates
}

Claire A. Wilson, Sarah E. Babcock, \& Donald H. Saklofske Western University

\begin{abstract}
The transition from high school to post-secondary education presents challenges for students. Many variables have been identified as significant predictors of student achievement. Resiliency, defined as the ability to overcome challenges and adversity, may be particularly relevant during the adjustment to post-secondary education. This study assesses whether resiliency incrementally predicts student success after controlling for additional predictors. Participants were 277 undergraduate students who completed self-reports of academic skills, resiliency, personality variables, emotional intelligence (EI), and perfectionism. Students' year-end GPA was collected from the university registrar. Hierarchical regression analysis revealed that resiliency, measured by sense of mastery, negatively predicted GPA after controlling for other predictors. The sense of mastery facet of self-efficacy positively predicted GPA; however, the adaptability facet was a significant negative predictor of GPA. Findings suggest that self-efficacy is a salient predictor of academic success, and that strong academic skills may serve as a protective factor for poor adaptability.
\end{abstract}

\section{Résumé}

La transition du secondaire au postsecondaire pose des défis aux étudiants. De nombreuses variables ont été identifiées comme des prédicteurs significatifs du rendement des élèves. La résilience, définie comme la capacité de surmonter les défis et l'adversité, peut être particulièrement pertinente lors de l'adaptation à l'éducation postsecondaire. Cette étude évalue si la 
résilience prédit progressivement la réussite de l'élève après le contrôle de facteurs prédictifs supplémentaires. Les participants étaient 277 étudiants de premier cycle qui avaient complété des auto-évaluations de compétences académiques, de résilience, de variables de personnalité, d'intelligence émotionnelle (IE), et de perfectionnisme. La moyenne pondérée cumulative (MPC) de fin d'année des étudiants a été recueilli auprès du registraire de l'université. Une analyse de régression hiérarchique a révélé que la résilience, mesurée par le sens de la maîtrise, prédisait négativement la MPC après avoir contrôlé les autres prédicteurs. La facette du sens de la maîtrise de l'autoefficacité prédisait positivement la MPC, cependant, la facette d'adaptabilité était un prédicteur négatif significatif de la MPC. Nos résultats suggèrent que l>auto-efficacité est un facteur prédictif important de la réussite scolaire et que de solides compétences académiques peuvent constituer un facteur de protection pour une faible adaptabilité.

\section{Introduction}

Post-secondary success and student retention in North America has been widely studied. However, in recent years, researchers are discovering that students entering postsecondary education are not necessarily following the traditional path to degree completion (Finnie \& Qiu, 2008; Parker \& Baldwin, 2009). Some students withdraw for various reasons but later return, others change programs and take longer to complete their degree (Finnie \& Qiu, 2009; Martinello, 2007; Shaienks, Eisl-Culkin, \& Bussière, 2006), while still others withdraw or fail and do not return for further education (Shaienks, Gluszynski, \& Bayard, 2008). While considerable research has examined various factors that may contribute to student retention, the salient feature among these varying patterns of degree completion is that some students manage to persist in their studies despite adversity and significant challenges. As Parker and Baldwin (2009) noted, this distinction between students who persist in their educational attainment despite setbacks and those who withdraw may be due to personal resiliency.

Resiliency, the ability to adapt and thrive when faced with adversity (Masten, 2001, 2014; Masten \& Wright, 2009), is a particularly prominent concept when examining life transitions, but is severely understudied in relation to post-secondary success and retention. The transition into post-secondary education is one particular adjustment that an increasing number of young people are experiencing; however, the majority of research examining resiliency in education is focused specifically on disadvantaged or marginalized groups. Resiliency as a trait is based on core developmental systems that are relevant to many groups of individuals (Masten, 2001, 2004; Prince-Embury, 2006, 2007) and thus may be influential in understanding student success more generally. With the increasing number of young adults enrolling in post-secondary education (Association of Universities and Colleges of Canada, 2011; Snyder, de Brey, \& Dillow, 2016), it is imperative we improve our understanding of persistence, and ultimately success, in post-secondary education. Student success in the present study is operationally defined as academic achievement measured by grade point average (GPA). While "success" can be conceptualized in many ways and may be considered a subjective term, academic achievement in post-secondary education is particularly relevant, and ultimately has a significant effect on retention and 
successful degree completion (e.g., Allen, Robbins, Casillas, \& Oh, 2008; Kirby \& Sharpe, 2001; McGrath \& Braunstein, 1997) Therefore, the present research aims to examine three factors of personal resiliency (Prince-Embury, 2006, 2007; Prince-Embury, Saklofske, \& Nordstokke, 2017) as predictors of post-secondary student success after controlling for other previously identified psychological success predictors. The present research is the first phase of a longitudinal study examining resiliency and personal characteristics associated with student success and retention at a North American university.

\section{Predictors of Student Success}

There have been numerous studies that have examined predictors of student success and retention versus failure and early leaving (e.g., Stelnicki, Nordstokke, \& Saklofske, 2015). The factors examined include a variety of demographic variables (e.g., Porchea, Allen, Robbins, \& Phelps, 2010) such as gender and parental education (e.g., Andres, AdamutiTrache, Yoon, Pidgeon, \& Thomsen, 2007), educational expectations (Andres et al., 2007), personality and motivation (e.g., Kappe \& van der Flier, 2012), institutional satisfaction and social involvement (e.g., Robbins et al., 2004), and intelligence and cognitive ability (e.g., Harackiewicz, Barron, Tauer, \& Elliot, 2002). However, the present research focuses on the contribution of personality and individual difference characteristics to achievement in a post-secondary setting. Three factors examined in the post-secondary achievement literature as significant predictors of success are the Big Five personality traits, trait emotional intelligence (EI), and perfectionism. While these factors are frequently researched, they are usually examined in isolation from one another. Therefore, in order to examine how these key factors incrementally predict achievement, they must be studied together.

\section{Personality}

When examining the relationship between academic success and general personality characteristics, the most frequently assessed traits are the Big Five personality traits. Conscientiousness (e.g., Barrick \& Mount, 1991; Noftle \& Robins, 2007; Richardson \& Abraham, 2009; Saklofske, Austin, Mastoras, Beaton, \& Osborne, 2012), agreeableness (e.g., Saklofske et al., 2012; Shiner, Masten, \& Roberts, 2003), and openness (e.g., Bauer \& Liang, 2003; Moses et al., 2011; Noftle \& Robins, 2007) are consistently indicated as significant positive predictors of GPA or other indicators of academic success, with conscientiousness being the strongest overall predictor (Poropat, 2009; Richardson, Abraham, \& Bond, 2012; Rimfeld, Kovas, Dale, \& Plomin, 2016; Sobowale, Ham, Curlin, \& Yoon, 2018; Stajkovic, Bandura, Locke, Lee, \& Sergent, 2018; Vedel, 2014). The research examining the relationship between neuroticism and GPA is mixed, with some studies finding significant negative relationships (e.g., Chamorro-Premuzic, 2006; ChamorroPremuzic \& Furnham, 2003) and others finding significant positive relationships (e.g., Musgrave-Marquart, Bromley, \& Dalley, 1997; Noftle \& Robins, 2007; Steele-Johnson \& Leas, 2013). Lastly, meta-analytic findings have indicated that extraversion is overwhelmingly not significantly associated with GPA (Vedel, 2014). Given the consistently strong relationships observed between certain Big Five traits and GPA, controlling for these factors when examining the contributions of other potentially relevant factors such as resiliency on GPA is warranted. 


\section{Trait Emotional Intelligence}

Trait EI describes the individual's self-perceptions of emotional competencies, captured through self-report measures (Petrides, Siegling, \& Saklofske, 2016). These emotional competencies are grouped according to higher-order factors such as well-being, self-control, emotionality, and sociability (Petrides, 2009), although each model has a somewhat different list of factors (e.g., Bar-On, 2004). These factors can be further broken down into a number of facets including, for example, emotion perception in self and others, emotion management, emotion regulation, trait empathy, impulse control, and emotion expression (Petrides, 2009).

The relationship between trait EI and academic success appears to be dependent on the criterion variable being assessed (e.g., GPA, retention) and the trait EI measure used. For instance, individuals who persist in post-secondary education after first year rank significantly higher on a variety of emotional competencies compared to those individuals who withdraw (Parker, Hogan, Eastabrook, Oke, \& Wood, 2006; Parker, Saklofske, \& Keefer, 2017). Further, gifted students who completed their undergraduate education scored significantly higher on adaptability, interpersonal ability, and stress management components of EI than gifted students who did not complete their degree (Parker et al., 2017). Similarly, certain facets of trait EI such as social responsibility and impulse control are positively associated with persisting and graduating from post-secondary education (Sparkman, Maulding, \& Roberts, 2009). On the other hand, other studies have found non-significant relationships between trait EI and objective academic performance scores (Bastian, Burns, \& Nettelbeck, 2005). The relationship between trait EI and GPA is less clear, with some studies reporting that trait EI positively predicts GPA (Parker, Summerfeldt, Hogan, \& Majeski, 2004) even after controlling for personality and cognitive abilities (Ferrando et al., 2010; Petrides, Frederickson, \& Furnham, 2004; Sanchez-Ruiz, Mavroveli, \& Poullis, 2013), while others have found no significant relationship between trait EI and GPA after controlling for the Big Five personality traits (Saklofske et al., 2012; Tok \& Morali, 2009) or cognitive test anxiety and coping strategies (Thomas, Cassady, \& Heller, 2017). Garg, Levin, and Tremblay (2016) also found that EI was not directly associated with GPA; however, it may indirectly influence GPA through adjustment to university. Additionally, Barchard (2003) found that only certain measures of trait EI predict GPA above and beyond personality and cognitive ability. Due to these inconsistent findings, it is necessary to further examine trait EI when assessing the incremental utility of resiliency when predicting GPA.

\section{Perfectionism}

Perfectionism is a personality trait that is characterized by setting extremely high standards for oneself and potentially others, being highly critical of oneself, and striving for flawlessness (Flett \& Hewitt, 2002; Frost, Marten, Lahart, \& Rosenblate, 1990).

Research examining the relationship between perfectionism and academic success frequently differentiates between perfectionistic strivings (adaptive perfectionism) and perfectionistic concerns (maladaptive perfectionism; Rice \& Ashby, 2007; Stoeber \& Otto, 2006). While some researchers argue that all forms of perfectionism are maladaptive (e.g., Smith et al., 2018), perfectionistic strivings are positively related to a variety of 
academic success outcomes, including better exam performance and higher GPA (e.g., Blankstein, Dunkley, \& Wilson, 2008; Castro \& Rice, 2003; Sevlever \& Rice, 2010; Verner-Filion \& Gaudreau, 2010).

In contrast, there is considerably less consensus concerning the relationship between perfectionistic concerns and academic performance, with some studies finding negative correlations and others not (e.g., Flett, Blankstein, \& Hewitt, 2009; Mobley, Slaney, \& Rice, 2005; Stoeber \& Otto, 2006). Further, studies have found that individuals who score high on the scales for adaptive perfectionism (Rice \& Slaney, 2002), maladaptive perfectionism (Grzegorek, Slaney, Franze, \& Rice, 2004), and the self-oriented subtype of perfectionism (Kljajic, Gaudreau, \& Franche, 2017) report higher GPAs compared to individuals who score low on perfectionism. Additionally, the relationship between perfectionism and academic achievement may be reciprocal, with recent research indicating that GPA predicts increases in both perfectionistic strivings and concerns (Damian, Stoeber, Negru-Subtirica, \& Băban, 2017). Therefore, given the significant positive relationship consistently found between perfectionistic strivings and academic performance, even after controlling for other factors (Stoeber, 2012), it is necessary to control for perfectionism when examining the predictive utility of resiliency in relation to student success.

\section{Resiliency}

Resiliency has been defined from multiple perspectives (Ellis, Bianchi, Griskevicius, \& Frankenhuis, 2017; Luthar, 2006; Masten, 2007; Prince-Embury \& Saklofske, 2013, 2014), but resiliency as a trait is believed to be formed from core developmental systems (Masten, 2001, 2014). Prince-Embury (2006, 2007, 2014) has proposed three core systems that are critical to resiliency development. Sense of mastery consists of feeling optimistic, having self-efficacy, and being adaptable, and is considered a protective factor in the face of adversity. Another protective factor is sense of relatedness, which comprises trusting others, having access to support, and feeling comfort with and tolerance of others. Alternatively, emotional reactivity is a risk factor that reflects how sensitive an individual is to negative emotions, how much this impairs their functioning, and how long it takes them to recover. Together, these three factors contribute to how resilient an individual is when faced with challenges or setbacks.

This three-factor model of personal resiliency (Prince-Embury, 2006, 2007, 2014) is particularly relevant to young adults entering post-secondary education. Individuals who score higher on sense of mastery and its facets are more confident in their abilities and therefore would be better equipped to deal with the new academic and personal challenges associated with post-secondary attainment. Further, for many students, entering postsecondary education involves moving away from well-established support networks; thus, having a greater sense of relatedness may make it easier to develop new relationships and support systems. Lastly, individuals who score high on emotional reactivity may experience greater emotional challenges when faced with new social and academic pressures (Prince-Embury et al., 2017). This three-factor model has been utilized in young adult samples in both Canada (Prince-Embury et al., 2017; Vesely, Saklofske, \& Nordstokke, 2014; Wilson et al., 2017) and Italy (Di Fabio \& Saklofske, 2018; Wilson et al., 2019). 


\section{Resiliency and Student Success}

While a variety of dispositional characteristics have been examined in relation to student achievement, resiliency is considerably understudied in this domain. However, some of the specific components of resiliency (e.g., self-efficacy, social support) have been examined in relation to student success. An early meta-analysis revealed that self-efficacy is a significant positive predictor of academic performance and persistence across a variety of methodologically unique studies (Multon, Brown, \& Lent, 1991). A more recent meta-analysis suggests that self-efficacy actually has a reciprocal relationship with academic performance, particularly in adults (Talsma, Schüz, Schwarzer, \& Norris, 2018). Further, academic selfefficacy positively predicts adjustment to college and cumulative GPA (Brady-Amoon \& Fuertes, 2011; Chemers, Hu, \& Garcia, 2001; Zajacova, Lynch, \& Espenshade, 2005), and research-related self-efficacy is a positive predictor of GPA (van der Westhuizen, de Beer, \& Bekwa, 2011). Optimism is another resiliency facet frequently associated with student success and achievement. General optimism (Aspinwall \& Taylor, 1992; Chemers et al., 2001) and academic optimism (Solberg Nes, Evans, \& Segerstrom, 2009) significantly predict GPA, and both academic and general optimism are associated with increased college adjustment and retention (Solberg Nes et al., 2009). Lastly, social support, a fundamental component of resiliency (Luthar, 2006), is positively associated with satisfaction during the college adjustment phase (Coffman \& Gilligan, 2002), and various positive academic behaviours (Purswell, Yazedjian, \& Toews, 2008). Perceived familial social support is also a positive predictor of GPA regardless of familial economic support, especially for women (Cheng, Ickes, \& Verhofstadt, 2012). Therefore, while previous research has indicated that certain aspects of resiliency positively predict student success outcomes, they are often examined independently, and without controlling for other salient factors.

While less frequently studied, resiliency-related risk factors (e.g., negative emotionality) are negatively related to GPA in middle-school students (Gumora \& Arsenio, 2002; Zhou, Main, \& Wang, 2010). Similarly, emotion regulation significantly predicts academic success in young schoolchildren (Graziano, Reavis, Keane, \& Calkins, 2007). However, the academic implications of poor emotional regulation and negative emotionality have primarily been studied in young students. Therefore, the relationship between emotional reactivity and success in college-aged students requires further exploration to establish if these relationships are consistent in post-secondary samples.

\section{Objectives and Hypotheses}

Given the changing pattern of degree completion observed in recent decades (Finnie \& Qiu, 2008; Parker \& Baldwin, 2009), it is important to determine more specifically what factors contribute to student success and retention in this new era of post-secondary education. The goal of the present study is to examine the predictive utility of both the protective and risk factors of resiliency as contributors to student success after controlling for previously identified predictors including personality (e.g., Stajkovic et al., 2018), EI (e.g., Parker et al., 2017), and perfectionism (e.g., Kljajic et al., 2017). It is hypothesized that (1) conscientiousness, agreeableness, openness, trait EI and perfectionism will significantly positively predict student success as measured by GPA, and given that previous research has indicated that related components of resiliency (i.e., self-efficacy, optimism, social support, negative 
emotionality) are predictive of a variety of domains of student success, it is further hypothesized that (2) mastery and relatedness will significantly positively predict student success as measured by objective GPA, and (3) emotional reactivity will be significantly negatively related to GPA even after controlling for personality, trait EI, and perfectionism.

\section{Method}

\section{Participants and Procedure}

Participants were recruited using a convenience sample of first-year undergraduate students from a large Canadian university. Participants consisted of 277 students (218 females, 59 males) aging from 17 to 38 years $(M=18.01, S D=1.46)$ and were $44.4 \%$ Caucasian. Students' residency status consisted of $86.3 \%$ domestic, $11.2 \%$ international, and 2.5\% permanent resident, which is representative of the present study's student population. Participants were enrolled in a number of degree programs, including health $/ \mathrm{medi}$ cal sciences (43\%), social science (17\%), science (13\%), business management (18\%), arts and humanities (3\%), and other (6\%). While the number of females in this sample is high (75\%), it is generally in line with the ratio of females to males in the national sample for these programs, particularly for health (77\% female) and social science programs (67\% female; Turcotte, 2011). The study was advertised online in the university's research participation pool system. To be eligible, participants had to be full-time first-year students, and interested participants completed a series of online questionnaires in September of their first year. The total study time was approximately 30 minutes, and participants received credit for their respective course requirements and were entered into a draw for gift cards as compensation for their participation. Students' final first-year GPAs were obtained from the university registrar's office upon completion of the academic year in May 2017.

\section{Measures}

Personality. The Big Five personality factors (extraversion, conscientiousness, openness, agreeableness, and neuroticism) were measured using the Mini-International Personality Item Pool scale (Mini-IPIP; Donnellan, Oswald, Baird, \& Lucas, 2006). The 20 items are assessed on a 5-point Likert scale ranging from 1 (very inaccurate) to 5 (very accurate). Research has indicated acceptable reliability and validity of the MiniIPIP (e.g., Baldasaro, Shanahan, \& Bauer, 2013).

Trait emotional intelligence. Global trait EI was measured using the 30-item short form of the Trait Emotional Intelligence Questionnaire (TEIQue-SF; Petrides \& Furnham, 2004). Participants responded to items on a 7-point Likert scale ranging from 1 (completely disagree) to 7 (completely agree). Previous research supports the reliability and validity of the TEIQue-SF (e.g., Petrides \& Furnham, 2006; Siegling, Vesely, Petrides, \& Saklofske, 2015).

Perfectionism. The Big Three Perfectionism Scale (BTPS; Smith, Saklofske, Stoeber, \& Sherry, 2016) is a 45-item scale that assesses three higher-order perfectionism factors: rigid perfectionism, self-critical perfectionism, and narcissistic perfectionism. Responses are made on a 5-point scale ranging from 1 (strongly disagree) to 5 (strongly agree). Initial validation of the BTPS has demonstrated good validity and reliability (Smith et al., 2016). 
Resiliency. The Resiliency Scale for Young Adults (RSYA; Prince-Embury et al., 2017) is a 50-item questionnaire consisting of three factors and 10 underlying facets. Sense of mastery consists of the facets optimism, self-efficacy, and adaptability. Sense of relatedness consists of trust, comfort with others, tolerance, and access to support. Lastly, emotional reactivity, the risk factor, consists of sensitivity, recovery, and impairment. Responses are made on a 5-point Likert scale ranging from o (never) to 4 (almost always). Previous research has supported the reliability and validity of the RSYA (Prince-Embury et al., 2017; Wilson et al., 2019).

\section{Data Analytic Strategy}

Descriptive statistics, reliability analyses, bivariate correlations, and hierarchical multiple regression analysis were conducted in SPSS Version 22 (IBM Corp., 2013). Multiple regression analysis was conducted to test the hypothesis that resiliency would predict GPA after controlling for personality, trait EI, and perfectionism. The independent variables consisting of personality, trait EI, perfectionism, and resiliency were entered sequentially in four hierarchical models to assess the incremental validity of each predictor on the dependent variable GPA.

\section{Results}

\section{Descriptive Statistics and Correlations}

Skewness and kurtosis values were evaluated for all major study variables. None of the study variables surpassed recommended skewness ( $> \pm$ 3.0; Curran, West, \& Finch, 1997) and kurtosis cutoffs ( $> \pm 10.0$; Kline, 2011) and therefore, given the normality of the data, parametric statistics were appropriate. Cronbach's alpha reliabilities, means, standard deviations, and bivariate correlations for all variables are presented in Table 1. Trait EI was positively associated with all of the Big Five traits with the exception of neuroticism, which had a significant negative correlation. Rigid, self-critical, and narcissistic perfectionism were all generally negatively related to the Big Five traits, while neuroticism was positively correlated. Sense of mastery and sense of relatedness were significantly positively related to trait EI, extraversion, openness, conscientiousness, and agreeableness, and negatively correlated with neuroticism and the rigid and self-critical perfectionism factors. Emotional reactivity was negatively related to trait EI, openness, conscientiousness, and agreeableness, and positively correlated with neuroticism and the three perfectionism factors. Final GPA was significantly negatively correlated with extraversion, and positively correlated with conscientiousness and rigid perfectionism.

\section{Hierarchical Multiple Regression Analyses}

Extraversion, conscientiousness, openness, agreeableness, and neuroticism were entered in Step 1. Trait EI was entered in Step 2. The three perfectionism factors, rigid perfectionism, self-critical perfectionism, and narcissistic perfectionism, were entered in Step 3. Lastly, the three resiliency factors, sense of mastery, sense of relatedness, and emotional reactivity, were entered in Step 4. Examination of variance inflation factor (VIF) and tolerance values revealed no concerns of multicollinearity. 


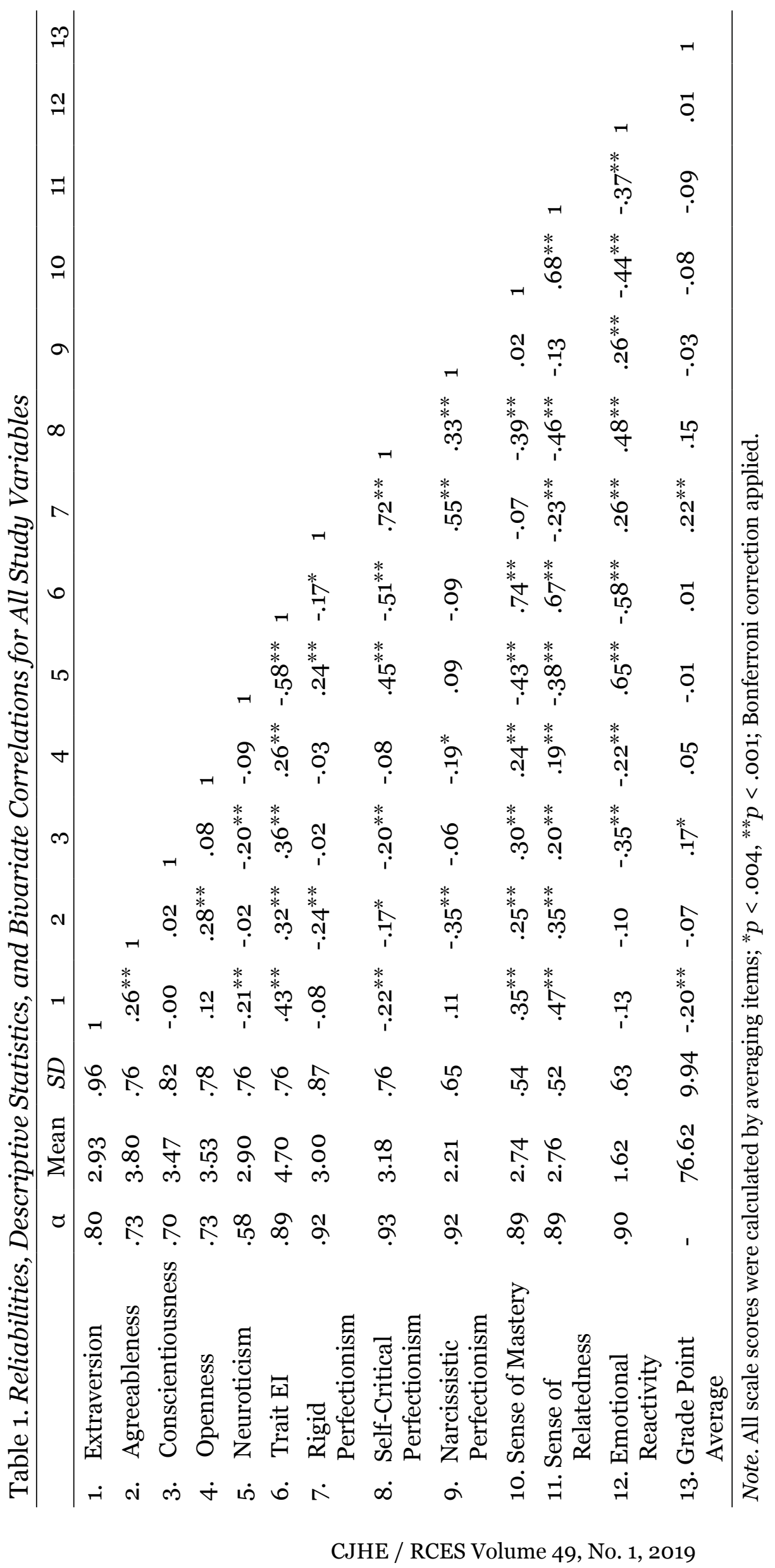


The Big Five personality variables accounted for a significant proportion of the variance in GPA, $R^{2}=.08, F(5,271)=4.40, p=.001$, however, only extraversion and conscientiousness were significant predictors of GPA (see Table 2). In Step 2, trait EI did not significantly predict GPA above and beyond personality variables, $R^{2}$ change $=.00, F(1,270)=0.28, p$ $=.597$. The model at Step 3 including perfectionism was statistically significant, $R^{2}$ change $=.07, F(3,267)=6.78, p<.001$. Rigid perfectionism and narcissistic perfectionism, but not self-critical perfectionism, significantly predicted GPA above and beyond personality and trait EI (see Table 2). Lastly, the model at Step 4 including resiliency was statistically significant, $R^{2}$ change $=.03, F(3,264)=2.80, p=.041$. However, sense of mastery was the only resiliency factor that accounted for a significant proportion of variance in GPA after controlling for the other independent variables (see Table 2). These results demonstrate that certain resiliency factors (i.e., mastery) account for a significant proportion of the variance in GPA even after individual differences in personality, trait EI, and perfectionism are controlled for. However, sense of mastery is a significant negative predictor of GPA, which contradicts hypotheses as well as previous related literature. Therefore, the authors considered further post-hoc analyses to better understand the results.

\section{Post-Hoc Analyses}

Regression analysis. The hierarchical regression analysis revealed that while sense of mastery was a significant predictor of GPA above and beyond the other independent variables, the regression coefficient was negative, and not in the expected direction. Therefore, an additional regression analysis was conducted post-hoc to examine the independent contributions of each mastery facet (i.e., adaptability, optimism, and self-efficacy) on GPA to determine which facets specifically were driving this negative relationship. The model with optimism, self-efficacy, and adaptability as predictors of GPA was significant, $R^{2}=.04, F(3,273)=3.52, p=.016$ (see Table 3 ). Consistent with previous research, selfefficacy was a significant positive predictor of GPA. However, contrary to expectations, adaptability was a significant negative predictor of GPA. Optimism was not a significant predictor in this model.

Mediation analysis. Given the negative association observed between adaptability and GPA, further post-hoc hypotheses were explored. After confirming the adaptability subscale had acceptable internal consistency $(\alpha=.78)$, the authors considered that adaptability may have a differential effect on academic outcomes depending on the person's specific learning skills and attitudes. As part of the demographic questionnaire, participants were asked questions pertaining to their academic skills and attitudes. While these data were not included in the initial analyses, they were available to include in a post-hoc examination. Thus, it was hypothesized that the association between adaptability and GPA would be mediated by an individual's academic skills and attitudes. Mediation analysis was conducted in Mplus version 8 (Muthén \& Muthén, 1998-2011). 
Table 2. Summary of Hierarchical Regression Analysis with Personality, Trait EI, Perfectionism and Resiliency as Predictors of Grade Point Average (GPA).

\begin{tabular}{|c|c|c|c|c|c|}
\hline & $B$ & Std. Error & $\beta$ & $t$ & $p$-value \\
\hline \multicolumn{6}{|l|}{ Step 1} \\
\hline Extraversion & -2.05 & .64 & -.20 & -3.19 & .002 \\
\hline Agreeableness & -.62 & .84 & -.05 & -.74 & .458 \\
\hline Conscientiousness & 1.98 & .73 & .16 & 2.72 & .007 \\
\hline Openness & .923 & .79 & .07 & 1.18 & .240 \\
\hline Neuroticism & -.28 & .80 & -.02 & -.35 & .729 \\
\hline \multicolumn{6}{|l|}{ Step 2} \\
\hline Extraversion & -2.18 & .69 & -.21 & -3.17 & .002 \\
\hline Agreeableness & -.74 & .87 & -.06 & -.85 & .394 \\
\hline Conscientiousness & 1.83 & .78 & .15 & 2.35 & .019 \\
\hline Openness & .85 & .80 & .07 & 1.06 & .288 \\
\hline Neuroticism & .01 & .96 & .00 & .01 & .995 \\
\hline Trait EI & .61 & 1.15 & .05 & .53 & .597 \\
\hline \multicolumn{6}{|l|}{ Step 3} \\
\hline Extraversion & -1.81 & .69 & -.18 & -2.62 & .009 \\
\hline Agreeableness & -.56 & .92 & -.04 & -.61 & .546 \\
\hline Conscientiousness & 1.69 & .76 & .14 & 2.23 & .027 \\
\hline Openness & .36 & .79 & .03 & .45 & .651 \\
\hline Neuroticism & -.81 & .96 & -.06 & -.84 & .400 \\
\hline Trait EI & .86 & 1.22 & .07 & .71 & .480 \\
\hline Rigid Perfectionism & 3.22 & 1.15 & .29 & 2.81 & .005 \\
\hline Self-Critical Perfectionism & .66 & 1.34 & .05 & .49 & .622 \\
\hline Narcissistic Perfectionism & -2.63 & 1.14 & -.17 & -2.31 & .021 \\
\hline \multicolumn{6}{|l|}{ Step 4} \\
\hline Extraversion & -1.87 & .71 & -.18 & -2.64 & .009 \\
\hline Agreeableness & -.53 & .92 & -.04 & -.58 & .566 \\
\hline Conscientiousness & 2.03 & .76 & .17 & 2.66 & .008 \\
\hline Openness & .70 & .79 & .05 & .88 & .380 \\
\hline Neuroticism & -1.69 & 1.07 & -.13 & -1.58 & .116 \\
\hline Trait EI & 2.84 & 1.43 & .22 & 1.99 & .048 \\
\hline Rigid Perfectionism & 3.60 & 1.14 & .32 & 3.15 & .002 \\
\hline Self-Critical Perfectionism & -.06 & 1.35 & -.00 & -.04 & .967 \\
\hline Narcissistic Perfectionism & -2.73 & 1.17 & -.18 & -2.35 & .020 \\
\hline Sense of Mastery & -3.66 & 1.71 & -.20 & -2.15 & .033 \\
\hline Sense of Relatedness & .03 & 1.69 & .00 & .02 & .985 \\
\hline Emotional Reactivity & 2.32 & 1.38 & .15 & 1.68 & .093 \\
\hline
\end{tabular}

Note. Significant predictors are bolded. 
Table 3. Summary of Standard Regression Analysis with the Sense of Mastery Facets as Predictors of GPA.

\begin{tabular}{lccccccc}
\hline & Mean & $S D$ & $B$ & Std. Error & $\beta$ & $t$ & $p$-value \\
\hline Optimism & 2.92 & .71 & -.67 & 1.12 & -.05 & -.60 & .551 \\
Self-Efficacy & 2.75 & .57 & 2.85 & 1.35 & .16 & 2.12 & .035 \\
Adaptability & 2.57 & .66 & -3.01 & 1.13 & -.20 & -2.67 & .008 \\
\hline
\end{tabular}

Note. Significant predictors are bolded.

The post-hoc mediation model consisted of the latent variable adaptability being regressed on the observed variable GPA through the latent variable academic skills. Academic skills consists of seven items pertaining to attitudes and beliefs surrounding academic and learning skills (e.g., "I have good study skills"). Adaptability consists of the five items that comprise the adaptability facet of the RSYA (e.g., "I can make major changes in my life when I need to"). As hypothesized, academic skills mediated the relationship between adaptability and GPA (see Figure 1). The direct effect of adaptability on GPA was significantly negative and the indirect effect of adaptability on GPA through academic skills was significantly positive, indicating inconsistent mediation and a potential suppression effect (see Table 4). Inconsistent mediation occurs when the direct effect and the mediated effects have opposite signs (MacKinnon, Krull, \& Lockwood, 2000). Therefore, the effects of individual adaptability on GPA are not clear unless differences in academic skills are also considered. This finding suggests that in an academic setting, individuals who score low on adaptability but possess strong learning skills and attitudes may be more likely to have a higher GPA.

Table 4. Decomposition for Effects of Adaptability on Academic Skills and GPA

\begin{tabular}{|c|c|c|c|c|}
\hline & \multicolumn{4}{|c|}{ Adaptability } \\
\hline & \multicolumn{2}{|c|}{ Estimates } & \multicolumn{2}{|c|}{ Bootstrapped 95\% bias-corrected Cl } \\
\hline & Unstandardized & Standardized & Unstandardized & Standardized \\
\hline \multicolumn{5}{|l|}{ Academic Skills } \\
\hline Direct Effect & .21 & .22 & .08 to .35 & $.08-.34$ \\
\hline \multicolumn{5}{|l|}{ GPA } \\
\hline Direct Effect & $-5.62^{* *}$ & $-.26 * *$ & -8.04 to -3.52 & -.36 to -.16 \\
\hline Total Effect & $-3.73^{*}$ & $-.18 *$ & -6.29 to -1.34 & -.29 to -.06 \\
\hline Indirect Effect & $1.89^{*}$ & $.09^{*}$ & .74 to 3.43 & .04 to .16 \\
\hline
\end{tabular}

Note. ${ }^{* *}=p<.01,{ }^{*}=p<.05$ 


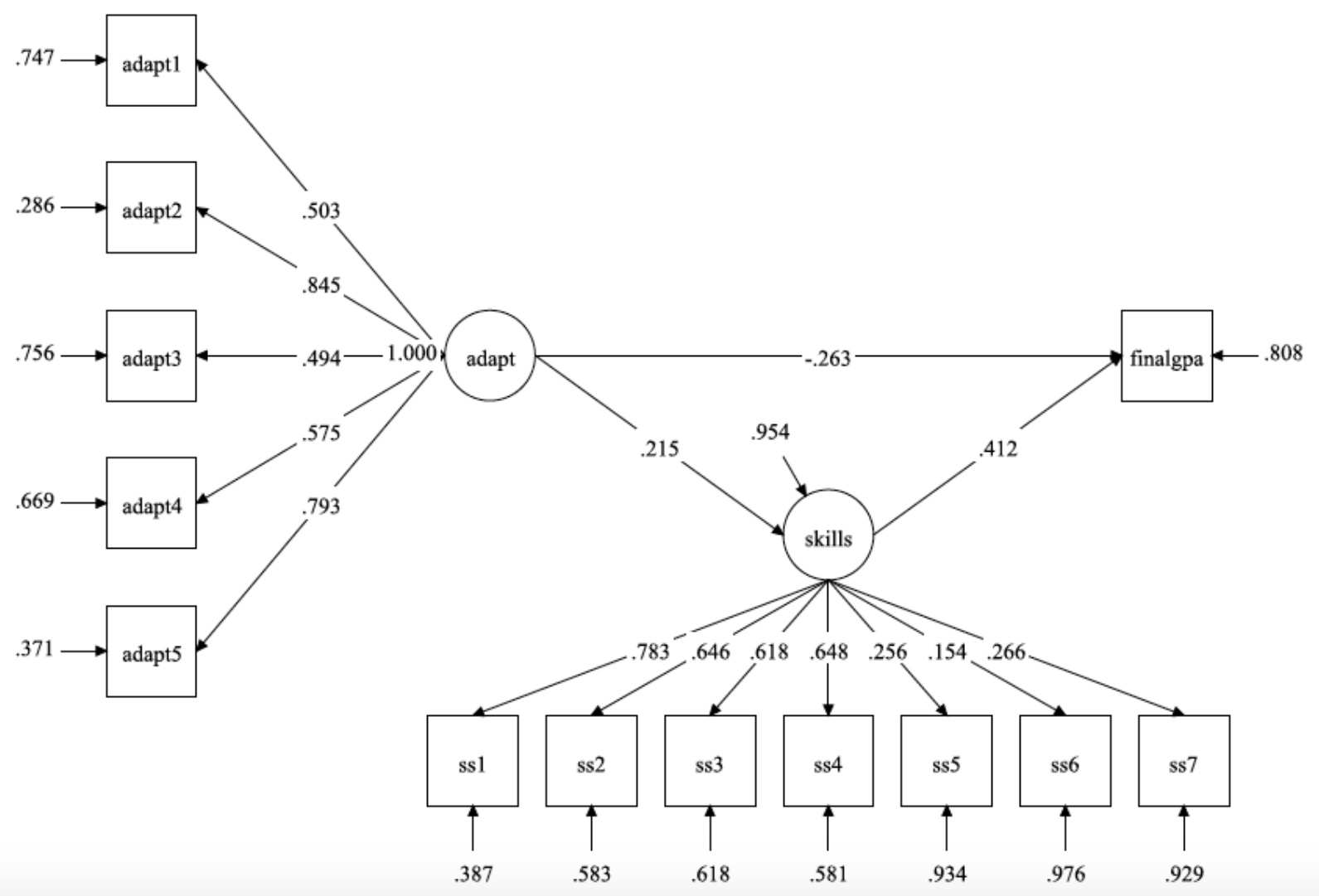

Figure 1. Standardized results of the mediation model demonstrating the relationship between adaptability, academic skills, and GPA with academic skills as a mediator.

\section{Discussion}

Correlations of resiliency, personality, and perfectionism variables with GPA were largely consistent with prior research. Final GPA was significantly positively correlated with rigid perfectionism, in line with prior research (e.g., Grzegorek et al., 2004). While perfectionists may be more likely to have a high GPA, perfectionism is often associated with many maladaptive outcomes (e.g., Smith et al., 2018), and therefore other indicators of student success (e.g., quality of life, school-life balance, well-being) might be negatively affected. Longitudinal studies are needed to examine the long-term implications of high perfectionism on academic success. As expected, conscientiousness was also significantly positively correlated with GPA (e.g., Stajkovic et al., 2018); however, a significant negative correlation between extraversion and final GPA was observed. While this differs from other research, which generally found no association (Vedel, 2014), the authors suggest that it was perhaps observed in this sample because all participants were first-year students who are attempting to adapt to university life, including developing new learning strategies, often living away from home and gaining independence, as well as making new friends and joining new activities. Extraverts may be more likely to partake in many of the social events and campus initiatives in an attempt to meet new people and get involved, which could have a negative effect on their grades, particularly in their first year of study. 
While none of the resiliency factors were significantly correlated with GPA in the present study, sense of mastery does account for a proportion of variance in GPA when combined in a prediction model with other relevant factors (i.e., perfectionism, conscientiousness, extraversion). Perhaps on its own mastery is not directly associated with GPA, but in combination with other traits it becomes influential. This suggests that there may be a "success constellation" or a group of traits that, when they appear together, result in increased likelihood of achieving academic success.

With regards to the hierarchical multiple regression, the Big Five personality variables accounted for a significant proportion of the variance in attained GPA; however, extraversion and conscientiousness were the only significant predictors of GPA in this sample. These results are partially consistent with previous findings in this area that demonstrate that conscientiousness is a positive and strong predictor of GPA (e.g., Richardson et al., 2012). A significant prediction between agreeableness or openness and GPA was not found, in contrast to what has typically been observed. As previously noted, the relationship between neuroticism and GPA has produced mixed results; therefore, our findings are in line with other samples that have found non-significant relationships. Further, the results of the regression suggest that trait EI did not significantly predict GPA above and beyond the Big Five personality variables. While EI is usually significantly linked with academic success, the results observed in this model are consistent with research findings by Bastian, Burns, and Nettelback (2005), who found that trait EI did not predict academic achievement, nor other "life skills," over and above personality variables and cognitive ability. Therefore, while perhaps significant in isolation, when trait EI is considered within the context of overarching personality characteristics, the influence on academic success appears to dissipate.

Moreover, this regression model demonstrated that perfectionism was a significant predictor in the model above and beyond personality and EI traits, and, specifically, that both rigid perfectionism and narcissistic perfectionism were significant predictors of GPA. Consistent with previous literature, this suggests that, in some capacity, perfectionistic tendencies are significantly linked with school performance. Specifically, while the literature is mixed in terms of which facets of perfectionism are associated, our data suggest that the rigid perfectionistic aspects concerned with strivings and high sense of self (which some refer to as adaptive perfectionism) are significantly and positively linked with higher GPA, while self-critical perfectionism does not seem to significantly influence GPA. Finally, a statistically significant influence of resiliency on GPA, above and beyond all other measures in the model, was found; albeit, sense of mastery was the only resiliency factor that accounted for a significant proportion of variance in GPA and was a significant negative predictor of GPA. This finding contradicted both our hypotheses and previous literature in this area.

Given the unexpected results of the resiliency component of the model, sense of mastery facets were further examined to better understand the relationship between resiliency and GPA. Using a mediation model composed of latent variables, we observed that the adaptability component of this factor showed a negative relationship with GPA, which is inconsistent with literature regarding adaptability and various markers of success. Since the specific academic context was possibly driving a differential effect, further analyses indicated that the association between adaptability and GPA was in fact mediated by an 
individual's academic skills and attitudes, suggesting that even if one had low adaptability, possessing strong academic skills and attitudes could have a positive effect on GPA. This finding, while unexpected from initial study hypotheses, makes conceptual sense. Those students who are high-functioning, prepared, and interested in the course material may not need to manifest greater adaptability to change in an academic context (e.g., examination style, lecture presentations) when transitioning to first-year university. For these students, their established study and academic behaviours may serve to protect them from the negative influence of low adaptability in other situations and contexts.

In line with these findings is research presented by Aspinwall and Taylor (1992), who illustrated that those who possess desire for control had significantly lower grades; however, the adverse impact of desire for control was cancelled out by the positive impact this variable had on motivation. Therefore, it is possible that students with high desire for control persist longer in more difficult courses, and therefore risk receiving lower grades than students who switch to majors that are less demanding. There is a logical link between the concepts of adaptability and control, and therefore the results of the current study do not seem so surprising. Sparkman, Maulding, and Roberts (2012) showed that an individual's flexibility was negatively related to graduation status, and that flexibility was highest in those no longer enrolled. The authors concluded that it was plausible that students who possess high flexibility scores were more willing to transfer to another degree or institution of choice or to change careers altogether. All things considered, the adaptability finding in this paper is in line with other studies that examine conceptually similar concepts such as flexibility and desire for control, and therefore, this nuance in the resiliency construct may be an important consideration for other researchers, especially when examining resiliency in the context of educational success.

While these findings are interesting, it should be noted that although sense of mastery accounted for a statistically significant proportion of variance in GPA after controlling for personality, perfectionism, and trait EI, it did not diminish the contribution of other important factors. Extraversion, conscientiousness, and perfectionism remained significant contributors to student success even after the addition of the resiliency factors. Therefore, while statistically sense of mastery does influence students' GPA, it should not replace other relevant factors. Instead, as mentioned previously, resiliency factors like sense of mastery should be considered part of a constellation of traits that together help to explain individual differences in academic success. Resiliency factors may perhaps play a larger role in overall academic success factors such as degree completion or retention; however, longitudinal studies are needed to examine this relationship.

\section{Limitations}

While the study sample was overall ethnically diverse, it was predominately female. While university populations in Canada overall have proportionally more females compared to males (Turcotte, 2011), the present study's 75\% female sample is higher than the reported approximate 60\% female reported by Statistics Canada. Therefore, results need to be considered with this in mind, especially given sex differences often observed in some personality traits or psychological characteristics. There are additional potentially confounding variables in the present study's sample that need to be considered. For instance, marital status, number of dependents, and living arrangements may play a role in 
factors such as an individual's sense of relatedness. Further, this data was collected from a single university population and therefore may not generalize to other undergraduate samples or other groups of young adults. While the eventual goal of this study is to examine student success longitudinally, the present study collected data over the first year of university only; therefore, it is too soon to assess overall university retention or persistent rates at this time.

In terms of the study measures, this model of resiliency is one of many (Prince-Embury, Saklofske, \& Vesely, 2015). This study only assessed the three factors of resiliency associated with this model, and thus other components of resiliency may not have been captured in our findings. Further, most of the study measures were self-report assessments, and therefore share the limitations of other assessments using this measurement format (e.g., socially desirable responding). Finally, authors utilized one outcome variable to measure student success (GPA) because it was objective, pertinent to success, and attainable at the university level (rather than via self-report). However, there are other operational definitions of student success (e.g., quality of life, school-life balance, job attainment) that were not measured as a part of this study.

\section{Future Directions}

This study captured the Phase 1 data collected as a part of a longitudinal study. Therefore, authors plan to examine retention and academic persistence, as participants have consented to have their academic success monitored over the course of their degree. Authors intend to capture variables such as completion of degree, change in program, and withdrawal date, and examine how this relates to personal levels of resiliency.

Further, given that adaptability is conceptually understood as a protective factor of resiliency and personal functioning, qualitative interviews or collection of information would be helpful in more fully understanding the relationship between adaptability and academic skills, and how this might predict academic success. More rich information regarding the student experience may allow researchers to pinpoint the unique interplay between these individual characteristics and how they manifest themselves in a post-secondary context.

\section{References}

Allen, J., Robbins, S. B., Casillas, A., \& Oh, I. S. (2008). Third-year college retention and transfer: Effects of academic performance, motivation, and social connectedness. Research in Higher Education, 49(7), 647-664. https://doi.org/10.1007/s11162-008-9098-3

Andres, L., Adamuti-Trache, M., Yoon, E. S., Pidgeon, M., \& Thomsen, J. P. (2007). Educational expectations, parental social class, gender, and postsecondary attainment: A 10-year perspective. Youth \& Society, 39(2), 135-163. https://doi. org/10.1177/0044118Xo6296704

Aspinwall, L. G., \& Taylor, S. E. (1992). Modeling cognitive adaptation: A longitudinal investigation of the impact of individual differences and coping on college adjustment and performance. Journal of Personality and Social Psychology, 63, 989-1003. http:// dx.doi.org/10.1037/0022-3514.63.6.989 
Association of Universities and Colleges of Canada (2011). Trends in higher education: Volume 1-Enrolment. Ottawa, ON: AUCC.

Baldasaro, R. E., Shanahan, M. J., \& Bauer, D. J. (2013). Psychometric properties of the Mini-IPIP in a large, nationally representative sample of young adults. Journal of Personality Assessment, 95(1), 74-84. https://doi.org/10.1080/00223891.2012.700466

Bar-On, R. (2004). The Bar-On Emotional Quotient Inventory (EQ-i): Rationale, description and summary of psychometric properties. In G. Geher (Ed.), Measuring emotional intelligence: Common ground and controversy (pp. 115-145). Hauppauge, NY: Nova Science.

Barchard, K. A. (2003). Does emotional intelligence assist in the prediction of academic success? Educational and Psychological Measurement, 63(5), 840-858. https://doi. org/10.1177/o013164403251333

Barrick, M. R., \& Mount, M. K. (1991). The Big Five personality dimensions and job performance: A meta-analysis. Personnel Psychology, 44, 1-26. https://doi. org/10.1111/j.1744-6570.1991.tboo688.x

Bastian, V. A., Burns, N. R., \& Nettelbeck, T. (2005). Emotional intelligence predicts life skills, but not as well as personality and cognitive abilities. Personality and Individual Differences, 39(6), 1135-1145. http://dx.doi.org/10.1016/j.paid.2005.04.006

Bauer, K. W., \& Liang, Q. (2003). The effect of personality and precollege characteristics on first-year activities and academic performance. Journal of College Student Development, 44(3), 277-290. https://doi.org/10.1353/csd.2003.0023

Blankstein, K. R., Dunkley, D. M., \& Wilson, J. (2008). Evaluative concerns and personal standards perfectionism: Self-esteem as a mediator and moderator of relations with personal and academic needs and estimated GPA. Current Psychology, 27(1), 2961. http://dx.doi.org/10.1007/s12144-008-9022-1

BradyAmoon, P., \& Fuertes, J. N. (2011). Self-efficacy, self-rated abilities, adjustment, and academic performance. Journal of Counseling \& Development, 89(4), 431-438. https://doi.org/10.1002/j.1556-6676.2011.tbo2840.x

Castro, J. R., \& Rice, K. G. (2003). Perfectionism and ethnicity: Implications for depressive symptoms and self-reported academic achievement. Cultural Diversity and Ethnic Minority Psychology, 9(1), 64-78. http://dx.doi.org/10.1037/1099-9809.9.1.64

Chamorro-Premuzic, T., \& Furnham, A. (2003). Personality predicts academic performance: Evidence from two longitudinal university samples. Journal of Research in Personality, 37(4), 319-338. https://doi.org/10.1016/Soo92-6566(02)o0578-o

Chamorro-Premuzic, T. (2006). Creativity versus conscientiousness: Which is a better predictor of student performance? Applied Cognitive Psychology, 2O(4), 521-531. http:// dx.doi.org/10.1002/acp.1196

Chemers, M. M., Hu, L. T., \& Garcia, B. F. (2001). Academic self-efficacy and first year college student performance and adjustment. Journal of Educational Psychology, 93(1), 55-64. http://dx.doi.org/10.1037/0022-0663.93.1.55 
Cheng, W., Ickes, W., \& Verhofstadt, L. (2012). How is family support related to students' GPA scores? A longitudinal study. Higher Education, 64(3), 399-420. https:// doi.org/10.1007/s10734-011-9501-4

Coffman, D. L., \& Gilligan, T. D. (2002). Social support, stress, and self-efficacy: Effects on students' satisfaction. Journal of College Student Retention: Research, Theory \& Practice, 4(1), 53-66. https://doi.org/10.2190/BV7X-F87X-2MXL-2B3L

Curran, P. J., West, S. G., \& Finch, J. F. (1997). The robustness of test statistics to non-normality and specification error in confirmatory factor analysis. Psychological Methods, 1, 16-29. http:// dx.doi.org/10.1037/1082-989X.1.1.16

Damian, L. E., Stoeber, J., Negru-Subtirica, O., \& Băban, A. (2017). On the development of perfectionism: The longitudinal role of academic achievement and academic efficacy. Journal of Personality, 85(4), 565-577. http://doi.org/10.1111/jopy.12261

Di Fabio, A., \& Saklofske, D. H. (2018). The contributions of personality and emotional intelligence to resiliency. Personality and Individual Differences, 123, 140-144. https:// doi.org/10.1016/j.paid.2017.11.012

Donnellan, M. B., Oswald, F. L., Baird, B. M., \& Lucas, R. E. (2006). The mini-IPIP scales: Tiny-yet-effective measures of the Big Five factors of personality. Psychological Assessment, 18(2), 192-203. https://doi.org/10.1037/1040-3590.18.2.192

Ellis, B. J., Bianchi, J., Griskevicius, V., \& Frankenhuis, W. E. (2017). Beyond risk and protective factors: An adaptation-based approach to resilience. Perspectives on Psychological Science, 12(4), 561-587. https://doi.org/10.1177/1745691617693054

Ferrando, M., Prieto, M. D., Almeida, L. S., Ferrándiz, C., Bermejo, R., López-Pina, J. A., ... Fernández, M. C. (2011). Trait emotional intelligence and academic performance: Controllingfortheeffects of IQ, personality, and self-concept.JournalofPsychoeducational Assessment, 29(2), 150-159. https://doi.org/10.1177/0734282910374707

Finnie, R., \& Qiu, T. (2008). The patterns of persistence in postsecondary education in Canada. MESA project research paper 2008-6. Toronto, ON: Canadian Education Project.

Finnie, R., \& Qiu, T. (2009). Moving through, moving on: Persistence in postsecondary education in Atlantic Canada, evidence from the PSIS. Statistics Canada, Culture, Tourism and the Centre for Education Statistics-Research Papers, Catalogue No. 81-595-M-No. 072. Ottawa, ON: Statistics Canada.

Flett, G. L., \& Hewitt, P. L. (2002). Perfectionism: Theory, research, and treatment. Washington, DC: American Psychological Association.

Flett, G. L., Blankstein, K. R., \& Hewitt, P. L. (2009). Perfectionism, performance, and state positive affect and negative affect after a classroom test. Canadian Journal of School Psychology, 24(1), 4-18. https://doi.org/10.1177/0829573509332457

Frost, R. O., Marten, P., Lahart, C., \& Rosenblate, R. (1990). The dimensions of perfectionism. Cognitive Therapy and Research, 14, 449-468. https://doi.org/10.1007/ BFo1172967

Garg, R., Levin, E., \& Tremblay, L. (2016). Emotional intelligence: Impact on postsecondary academic achievement. Social Psychology of Education, 19(3), 627-642. https://doi.org/10.1007/s11218-016-9338-x 
Graziano, P. A., Reavis, R. D., Keane, S. P., \& Calkins, S. D. (2007). The role of emotion regulation in children's early academic success. Journal of School Psychology, 45(1), 3-19. https://doi.org/10.1016/j.jsp.2006.09.002

Grzegorek, J. L., Slaney, R. B., Franze, S., \& Rice, K. R. (2004). Self-criticism, dependency, self-esteem, and grade-point average satisfaction among clusters of perfectionists and nonperfectionists. Journal of Counseling Psychology, 51, 192-200. http://dx.doi.org/10.1037/0022-0167.51.2.192

Gumora, G., \& Arsenio, W. F. (2002). Emotionality, emotion regulation, and school performance in middle school children. Journal of School Psychology, 40(5), 395-413. https://doi.org/10.1016/So022-4405(02)00108-5

Harackiewicz, J. M., Barron, K. E., Tauer, J. M., \& Elliot, A. J. (2002). Predicting success in college: A longitudinal study of achievement goals and ability measures as predictors of interest and performance from freshman year through graduation. Journal of Educational Psychology, 94(3), 562-575. http://dx.doi.org/10.1037/0022-0663.94.3.562

IBM Corp. (2013). IBM SPSS Statistics for Windows (Version 22.0). Armonk, NY: IBM Corp.

Kappe, R., \& van der Flier, H. (2012). Predicting academic success in higher education: What's more important than being smart? European Journal of Psychology of Education, 27(4), 605-619. https://doi.org/10.1007/s10212-011-0099-9

Kirby, D., \& Sharpe, D. (2001). Student attrition from Newfoundland and Labrador's public college. Alberta Journal of Educational Research, 47(4), 353-368.

Kline, R. B. (2011). Principles and practice of structural equation modeling (3rd ed.). New York: Guilford Publications Inc.

Kljajic, K., Gaudreau, P., \& Franche, V. (2017). An investigation of the $2 \times 2$ model of perfectionism with burnout, engagement, self-regulation, and academic achievement. Learning and Individual Differences, 57, 103-113. https://doi.org/10.1016/j. lindif.2017.06.004

Luthar, S. S. (2006). Resilience in development: A synthesis of research across five decades. In D. Cicchetti \& D. J. Cohen (Eds.), Developmental psychopathology: Risk, disorder, and adaptation ( ${ }^{\text {nd }}$ ed., Vol. 3, pp. 739-795). Hoboken, NJ: John Wiley.

MacKinnon, D. P., Krull, J. L., \& Lockwood, C. M. (2000). Equivalence of the mediation, confounding and suppression effect. Prevention Science, 1(4), 173-181. https://doi. org/10.1023/A:1026595011371

Martinello, F. (2007, October 19). Student transitions and adjustments in Canadian post-secondary education. Paper presented at the All in the Family: Evidence from the YITS on PSE Access and Persistence conference, hosted by the Canada Millennium Scholarship Foundation, Montreal, October 19.

Masten, A. S. (2001). Ordinary magic: Resilience processes in development. American Psychologist, 56, 227-238. http://dx.doi.org/10.1037/0003-066X.56.3.227

Masten, A. S. (2007). Resilience in developing systems: Progress and promise as the fourth wave rises. Development and Psychopathology, 19, 921-930. https://doi. org/10.1017/So954579407000442 
Masten, A. S. (2014). Ordinary magic: Resilience in development. New York, NY: Guilford Press.

Masten, A. S., \& Wright, M. O. (2009). Resilience over the lifespan. In J. W. Reich (Ed.), Handbook of adult resilience (pp. 213-237). New York, NY: Guilford Press.

McGrath, M., \& Braunstein, A. (1997). The prediction of freshmen attrition: An examination of the importance of certain demographic, academic, financial, and social factors. College Student Journal, 31 (3), 396-408.

Mobley, M., Slaney, R. S., \& Rice, K. G. (2005). Cultural validity of the Almost Perfect Scale-Revised for African American college students. Journal of Counseling Psychology, 52, 629-639. http://dx.doi.org/10.1037/0022-0167.52.4.629

Moses, L., Hall, C., Wuensch, K., De Urquidi, K., Kauffmann, P., Swart, W., . . . Dixon, G. (2011). Are math readiness and personality predictive of first-year retention in engineering? The Journal of Psychology, 145(3), 229-245. https://doi.org/10.1080/o0 223980.2011.557749

Multon, K. D., Brown, S. D., \& Lent, R. W. (1991). Relation of self-efficacy beliefs to academic outcomes: A meta-analytic investigation. Journal of Counselling Psychology, 38, 30-38. http://dx.doi.org/10.1037/0022-0167.38.1.30

Musgrave-Marquart, D., Bromley, S. P., \& Dalley, M. B. (1997). Personality, academic attribution, and substance use as predictors of academic achievement in college students. Journal of Social Behavior and Personality, 12(2), 501-511.

Muthén, L. K. and Muthén, B. O. (1998-2012). Mplus user's guide (6th ed.). Los Angeles, CA: Muthén \& Muthén.

Noftle, E. E., \& Robins, R. W. (2007). Personality predictors of academic outcomes: Big five correlates of GPA and SAT scores. Journal of Personality and Social Psychology, 93(1), 116-130. http://dx.doi.org/10.1037/o022-3514.93.1.116

Parker, A., \& Baldwin, N. (2009). Persistence in post-secondary education in Canada: The latest research. Millennium Research Note \#8. Montreal, QC: Millennium Scholarship Foundation.

Parker, J. D., Hogan, M. J., Eastabrook, J. M., Oke, A., \& Wood, L. M. (2006). Emotional intelligence and student retention: Predicting the successful transition from high school to university. Personality and Individual Differences, 41(7), 1329-1336. https://doi. org/10.1016/j.paid.2006.04.022

Parker, J. D., Saklofske, D. H., \& Keefer, K. V. (2017). Giftedness and academic success in college and university: Why emotional intelligence matters. Gifted Education International, 33(2), 183-194. https://doi.org/10.1177/0261429416668872

Parker, J. D., Summerfeldt, L. J., Hogan, M. J., \& Majeski, S. A. (2004). Emotional intelligence and academic success: Examining the transition from high school to university. Personality and Individual Differences, 36(1), 163-172. https://doi. org/10.1016/So191-8869(03)ooo76-X 
Petrides, K. V. (2009). Psychometric properties of the trait emotional intelligence questionnaire (TEIQue). In C. Stough, D. H. Saklofske, \& D. A. Parker (Eds.), Assessing emotional intelligence: Theory, research and practice (pp. 85-101). New York, NY: Springer US.

Petrides, K. V., \& Furnham, A. (2004). Technical manual of the Trait Emotional Intelligence Questionnaire (TEIQue). London, UK: University of London, Institute of Education.

Petrides, K.V.,\&Furnham,A. (2006). The roleoftrait emotional intelligencein a genderspecific model of organizational variables. Journal of Applied Social Psychology, 36(2), 552-569. http://dx.doi.org/10.1111/j.0021-9029.2006.00019.x

Petrides, K. V., Frederickson, N., \& Furnham, A. (2004). The role of trait emotional intelligence in academic performance and deviant behavior at school. Personality and Individual Differences, 36(2), 277-293. https://doi.org/10.1016/So191-8869(03)00084-9

Petrides, D., Siegling, A., \& Saklofske, D. H. (2016). Theory and measurement of trait emotional intelligence. In U. Kumar (Ed.), Wiley handbook of personality assessment (pp. 90-103). Chichester, UK: John Wiley \& Sons Ltd.

Porchea, S. F., Allen, J., Robbins, S., \& Phelps, R. P. (2010). Predictors of long-term enrollment and degree outcomes for community college students: Integrating academic, psychosocial, socio-demographic, and situational factors. The Journal of Higher Education, 81(6), 680-708. https://doi.org/10.1080/00221546.2010.11779077

Poropat, A. E. (2009). A meta-analysis of the five-factor model of personality and academic performance. Psychological Bulletin, 135(2), 322-338. http://dx.doi. org/10.1037/ao014996

Prince-Embury, S. (2006). Resiliency scales for adolescents: Profiles of personal strength. San Antonio, TX: Harcourt Assessment.

Prince-Embury, S. (2007). Resiliency scales for children and adolescents: Profiles of personal strength. San Antonio, TX: Harcourt Assessment.

Prince-Embury, S. (2014). A three-factor model of personal resilience and related assessment. In S. Prince-Embury \& D. Saklofske (Eds.), Resilience interventions for youth in diverse populations (pp. 25-57). New York, NY: Springer.

Prince-Embury, S., \& Saklofske, D. H. (2013). Translating resilience theory for application: Introduction. In S. Prince-Embury \& D. H. Saklofske (Eds.), Resilience in children, adolescents, and adults: Translating research into practice (pp. 3-7). New York, NY: Springer.

Prince-Embury, S., \& Saklofske, D. H. (2014). Building a science of resilience intervention for youth. In S. Prince-Embury \& D. H. Saklofske (Eds.), Resilience interventions for youth in diverse populations (pp. 3-12). New York, NY: Springer.

Prince-Embury, S., Saklofske, D. H., \& Nordstokke, D. W. (2017). The resiliency scale for young adults. Journal of Psychoeducational Assessment, 35(3), 276-290. https:// doi.org/10.1177/0734282916641866 
Prince-Embury, S., Saklofske, D. H., \& Vesely, K. V. (2015). Measures of resiliency. In G. J. Boyle, D. H. Saklofske, \& G. Matthews (Eds.), Measures of personality and social psychology constructs (pp. 290-321). San Diego, CA: Elsevier/Academic Press.

Purswell, K. E., Yazedjian, A., \& Toews, M. L. (2008). Students' intentions and social support as predictors of self-reported academic behaviors: A comparison of first- and continuing-generation college students. Journal of College Student Retention: Research, Theory \& Practice, 1O(2), 191-206. https://doi.org/10.2190/CS.10.2.e

Rice,K.G.,\&Ashby,J.S.(2007).Anefficientmethodforclassifyingperfectionists.Journal of Counseling Psychology, 54(1), 72-85. http://dx.doi.org/10.1037/0022-0167.54.1.72

Rice, K. G., \& Slaney, R. B. (2002). Clusters of perfectionists: Two studies of emotional adjustment and academic achievement. Measurement and Evaluation in Counseling and Development, 35, 35-48.

Richardson, M., \&Abraham, C. (2009). Conscientiousness and achievement motivation predict performance. European Journal of Personality, 23(7), 589-605. https://doi. org/10.1002/per.732

Richardson, M., Abraham, C., \& Bond, R. (2012). Psychological correlates of university students' academic performance: A systematic review and meta-analysis. Psychological Bulletin, 138(2), 353-387. http://dx.doi.org/10.1037/a0026838

Rimfeld, K., Kovas, Y., Dale, P. S., \& Plomin, R. (2016). True grit and genetics: Predicting academic achievement from personality. Journal of Personality and Social Psychology, 111(5), 780-789. http://dx.doi.org/10.1037/psppooooo89

Robbins, S. B., Lauver, K., Le, H., Davis, D., Langley, R., \& Carlstrom, A. (2004). Do psychosocial and study skill factors predict college outcomes? A meta-analysis. PsychologicalBulletin,103(2),261-288.http://dx.doi.org/10.1037/0033-2909.130.2.261

Saklofske, D. H., Austin, E. J., Mastoras, S. M., Beaton, L., \& Osborne, S. E. (2012). Relationships of personality, affect, emotional intelligence and coping with student stress and academic success: Different patterns of association for stress and success. Learning and Individual Differences, 22(2), 251-257. https://doi.org/10.1016/j.lindif.2011.02.010

Sanchez-Ruiz, M. J., Mavroveli, S., \& Poullis, J. (2013). Trait emotional intelligence and its links to university performance: An examination. Personality and Individual Differences, 54(5), 658-662. https://doi.org/10.1016/j.paid.2012.11.013

Sevlever, M., \& Rice, K. G. (2010). Perfectionism, depression, anxiety, and academic performance in premedical students. Canadian Medical Education Journal, 1(2), 96104.

Shaienks, D., Eisl-Culkin, J., \& Bussière, P. (2006). Follow-up on education and labour market pathways of young Canadians aged 18 to 2O-Results from YITS Cycle 3. Catalogue no. 81-595-MIE - No. 045. Ottawa, ON: Statistics Canada.

Shaienks, D., Gluszynski, T., \& Bayard, J. (2008). Postsecondary Education Participation and dropping out: Differences across university, college and other types of postsecondary institutions. Statistics Canada, Culture, Tourism and the Centre for Education Statistics Research Papers, Catalogue no. 81-595-M No. 070. Ottawa, ON: Statistics Canada. 
Shiner, R. L., Masten, A. S., \& Roberts, J. M. (2003). Childhood personality foreshadows adult personality and life outcomes two decades later. Journal of Personality, 71(6), 1145-1170. https://doi.org/10.1111/1467-6494.7106010

Siegling, A. B., Vesely, A. K., Petrides, K. V., \& Saklofske, D. H. (2015). Incremental validity of the Trait Emotional Intelligence Questionnaire-Short Form (TEIQueSF). Journal of Personality Assessment, 97(5), 525-535. https://doi.org/10.1080/0022 3891.2015.1013219

Smith, M. M., Saklofske, D. H. Stoeber, J., \& Sherry, S, B. (2016) The Big Three Perfectionism Scale: A new measure of perfectionism. Journal of Psychoeducational Assessment, 34(7), 670-687. https://doi.org/10.1177/0734282916651539

Smith, M. M., Sherry, S. B., Chen, S., Saklofske, D. H., Mushquash, C., Flett, G. L., \& Hewitt, P. L. (2018). The perniciousness of perfectionism: A meta-analytic review of the perfectionism-suicide relationship. Journal of Personality, 86(3), 522-542. https://doi. org/10.1111/jopy.12333

Snyder, T.D., de Brey, C., and Dillow, S.A. (2016). Digest of education statistics 2014 (NCES 2016-006). National Center for Education Statistics, Institute of Education Sciences. Washington, DC: United States Department of Education.

Sobowale, K., Ham, S. A., Curlin, F. A., \& Yoon, J. D. (2018). Personality traits are associated with academic achievement in medical school: A nationally representative study. Academic Psychiatry, 42(3), 338-345. https://doi.org/10.1007/s40596-0170766-5

Solberg Nes, L., Evans, D. R., \& Segerstrom, S. C. (2009). Optimism and college retention: Mediation by motivation, performance, and adjustment. Journal of Applied Social Psychology, 39(8), 1887-1912. https://doi.org/10.1111/j.1559-1816.2009.00508.x

Sparkman, L., Maulding, W., \& Roberts, J. (2012). Non-cognitive predictors of student success in college. College Student Journal, 46(3), 642-652.

Stajkovic, A. D., Bandura, A., Locke, E. A., Lee, D., \& Sergent, K. (2018). Test of three conceptual models of influence of the Big Five personality traits and self-efficacy on academic performance: A meta-analytic path-analysis. Personality and Individual Differences, 12O, 238-245. https://doi.org/10.1016/j.paid.2017.08.014

Steele-Johnson, D., \& Leas, K. (2013). Importance of race, gender, and personality in predicting academic performance. Journal of Applied Social Psychology, 43(8), 17361744. https://doi.org/10.1111/jasp.12129

Stelnicki, A. M., Nordstokke, D. W., \& Saklofske, D. H. (2015). Who is the successful university student? An analysis of personal resources. The Canadian Journal of Higher Education, 45(2), 214-228.

Stoeber, J. (2012). Perfectionism and performance. In S. Murphy (Ed.), The Oxford handbook of sport and performance psychology (pp. 294-307). Toronto, ON: Oxford University Press.

Stoeber, J., \& Otto, K. (2006). Positive conceptions of perfectionism: Approaches, evidence, challenges. Personality and Social Psychology Review, 1O, 295-319. https:// doi.org/10.1207/s15327957pspr1004_2 
Talsma, K., Schüz, B., Schwarzer, R., \& Norris, K. (2018). I believe, therefore I achieve (and vice versa): A meta-analytic cross-lagged panel analysis of self-efficacy and academic performance. Learning and Individual Differences, 61, 136-150. https://doi. org/10.1016/j.lindif.2017.11.015

Thomas, C. L., Cassady, J. C., \& Heller, M. L. (2017). The influence of emotional intelligence, cognitive test anxiety, and coping strategies on undergraduate academic performance. Learning and Individual Differences, 55, 40-48. https://doi.org/10.1016/j. lindif.2017.03.001

Tok, S., \& Morali, S. (2009). Trait emotional intelligence, the Big Five personality dimensions and academic success in physical education teacher candidates. Social Behavior and Personality: An International Journal, 37(7), 921-931. http://dx.doi. org/10.2224/sbp.2009.37.7.921

Turcotte, M. (2011). Women and education. Women in Canada: A gender-based statistical report, Catalogue No. 89-503-X. Ottawa, ON: Statistics Canada.

van der Westhuizen, S., de Beer, M., \& Bekwa, N. (2011). Psychological strengths as predictors of postgraduate students' academic achievement. Journal of Psychology in Africa, 21(3), 473-478. https://doi.org/10.1080/14330237.2011.10820485

Vedel, A. (2014). The Big Five and tertiary academic performance: A systematic review and meta-analysis. Personality and Individual Differences, 71, 66-76. https:// doi.org/10.1016/j.paid.2014.07.011

Verner-Filion, J., \& Gaudreau, P. (2010). From perfectionism to academic adjustment: The mediating role of achievement goals. Personality and Individual Differences, 49(3), 181-186. https://doi.org/10.1016/j.paid.2010.03.029

Vesely, A. K., Saklofske, D. H., \& Nordstokke, D. W. (2014). EI training and preservice teacher wellbeing. Personality and Individual Differences, 65, 81-85. https:// doi.org/10.1016/j.paid.2014.01.052

Wilson, C. A., Plouffe, R. A., Saklofske, D. H., Di Fabio, A., Prince-Embury, S., \& Babcock, S. E. (2019). Resiliency in young adults across cultures: A validation of the Resiliency Scale for Young Adults. Journal of Psychoeducational Assessment. Advanced online publication. https://doi.org/10.1177/0734282917740017

Zajacova, A., Lynch, S. M., \& Espenshade, T. J. (2005). Self-efficacy, stress, and academic success in college. Research in Higher Education, 46(6), 677-706. https://doi. org/10.1007/s11162-004-4139-z

Zhou, Q., Main, A., \& Wang, Y. (2010). The relations of temperamental effortful control and anger/frustration to Chinese children's academic achievement and social adjustment: A longitudinal study. Journal of Educational Psychology, 102(1), 180-196. https://doi.org/10.1037/a0015908 


\section{Contact Information}

Claire A. Wilson

Department of Psychology

University of Western Ontario

cwils26@uwo.ca

Claire Wilson is a PhD candidate at the University of Western Ontario in the Department of Psychology. Her current areas of research include resiliency and psychological predictors of successful aging in older adults, positive emotions, and psychosocial predictors of academic performance and retention of university undergraduate students.

Sarah E. Babcock is a PhD candidate at the University of Western Ontario in the social personality and developmental psychology area. Her research interests include individual differences, cognitive ability assessment, psycho-educational assessment, scale development, and resilience. Recent publications include Babcock et al., "WISC-V Canadian Norms: Relevance and Use in the Assessment of Canadian Children," Canadian Journal of Behavioural Science (2018). She previously worked for Pearson Clinical Assessment as project coordinator for Canadian adaptations of intelligence and behavioural assessment tools.

Dr. Donald Saklofske is a professor in the Department of Psychology, University of Western Ontario. Dr. Saklofske's research interests are focused on individual differences in intelligence and personality with a current emphasis on personality, emotional intelligence, resiliency, and psychological assessment. He has published 200 journal articles and more than 100 books and book chapters. He is editor of Personality and Individual Differences and the Journal of Psychoeducational Assessment, and he is an elected Fellow of APS, CPA, and SPSP. 